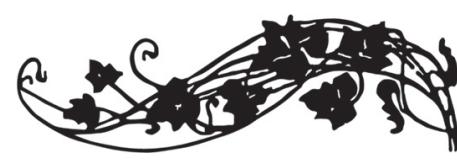

https://doi.org/10.31261/CHOWANNA.2020.55.08

s. 1 z 24

\section{Łukasz M. Michalski}

Uniwersytet Śląski w Katowicach

(iD https://orcid.org/0000-0002-2863-289X

\title{
Likwidacja Europy \\ Totalizm i demokracja \\ w rozważaniach Zygmunta Mysłakowskiego
}

\section{Liquidation of Europe: \\ Totalism and Democracy in the Reflections of Zygmunt Mysłakowski}

Abstract: Łukasz Michalski discusses the content of Zygmunt Mysłakowski's 1938 book Totalizm czy kultura (Totalism or Culture). He points to the consonance between book's diagnoses of the socio-political situation in the late 1930s and Timothy Snyder's description of the second decade of the twenty-first century. He argues that we can see an analogy between the dynamic growth of totalisms in the interwar period and the mechanisms that can be observed in Europe, America, Russia today. Mysłakowski and Snyder leave no illusions in their descriptions of their present milieus. However, in Mysłakowski's book there is a cognitive incongruity inasmuch as, alongside the main line of the argument with its recognition of the value of democracy, there is also an appreciation of the figure of the leader (Marshal Józef Piłsudski). Michalski examines this tension as the context of the diagnoses of our contemporary situation.

Keywords: totalism, culture, Zygmunt Mysłakowski, Józef Piłsudski, Timothy Snyder 
Wstapiliśmy $w$ okres coraz bardziej przyspieszonej, coraz bardziej gwattownej "likwidacji Europy" (w znaczeniu nie geograficznym oczywiście, lecz kulturalnym).

Zygmunt Mysłakowski

Myślenie historyczne oznacza przyjęcie do wiadomości, że rzeczy nam nieznane moga być znaczące, oraz wysiłek, by uczynić je znanymi².

Timothy Snyder

\section{Wstęp}

Książka Totalizm czy kultura autorstwa Zygmunta Mysłakowskiego została wydana po raz pierwszy w 1938 roku. Inicjowała serię mających się ukazywać co miesiąc „tanich i dobrych książek o charakterze społecznym i popularno-naukowym" Krakowskiej Spółdzielni Wydawniczej „Czytelnik”. Nie odbiła się jednak szerokim echem w środowisku naukowym. Realizację jej popularyzatorskich celów uniemożliwiła wojna. Ta niewielkich rozmiarów publikacja jest w znaczącej części analizą okoliczności autorowi współczesnych, a te wojna diametralnie zmieniła, co szybko uczyniło książkę w warstwie komentarza nieaktualną ${ }^{4}$, w czasach PRL-u zaś tekst był dyskwalifikowany z przyczyn ideowo zasadniczych. Nie jest to więc pozycja, która doczekała się powojennych wznowień czy jakiegoś renesansu lektury w kolejnych dekadach. Także dziś autorzy odnoszą się do niej w pracach naukowych dość rzadko, nie licząc kręgów badawczo zainteresowanych twórczością i czasami Zygmunta Mysłakowskiego. Sądzę, że zamieszczenie tutaj poszerzonego streszczenia Totalizmu czy kultury ma szansę na przywrócenie książki do obiegu czytelniczego (i jest to pierwsze zadanie niniejszego artykułu). Tym bardziej warto to zrobić, że choć od czasów ukazania się Totalizmu czy kultury minęło już ponad osiem dekad, dzisiejszy czytelnik chyba tylko z wysiłkiem uniknie odczucia podobieństwa czasów wydania książki i naszej współczesności - obojętne, czy z Mysłakowskim będzie się zgadzał, czy też nie.

${ }^{1}$ Z. Mysłakowski: Totalizm czy kultura. Kraków 1938, s. 13-14.

2 T. Snyder: Droga do niewolności. Rosja, Europa, Ameryka. Przekł. B. Pietrzyk. Kraków 2019, s. 32.

3 „Krakowski Kurier Wieczorny” 1938, nr 247, s. 6.

${ }^{4}$ Oczywiście nieaktualną tylko z pozoru i w opinii politycznie zaangażowanych środowisk kształtujących powojenną „prawomyślność” - wszak Totalizm czy kultura to bardzo pożyteczne narzędzie rozpoznania rzeczywistości PRL-u i gier właśnie z ową „prawomyślnością” prowadzonych. 
Czytający Czesława Miłosza Timothy Snyder ze Zniewolonego umysłu wyławia następujący cytat: „Dopiero w połowie XX wieku mieszkańcy wielu krajów europejskich zyskali, w sposób na ogół przykry, świadomość, że zawiłe i zbyt trudne dla przeciętnego śmiertelnika książki filozoficzne mają wpływ całkiem bezpośredni na ich losy" ${ }^{5}$. Z wywodu Snydera wynika, że XXI wiek nie musi się w tym względzie różnić od minionego stulecia. Autor rozważa znaczenie tekstów urodzonego w 1883 roku Iwana Iljina, o którym pisze: „To nie jedyny faszystowski myśliciel wyciągnięty z zapomnienia w naszym stuleciu, ale najważniejszy spośród nich. Jest przewodnikiem na coraz mroczniejszej drodze do niewolności"6. Nic więc sentymentalnego w wyciąganiu z zapomnienia - to niezbędne; to jednak także niebezpieczne. Strategią obrony przed zagrożeniami byłoby dbanie o możliwie szeroki repertuar znalezisk i „archeologicznych” strategii poszukiwań. Są bowiem takie książki, które wyrządzają szkodę właśnie tym, że swojego potencjalnego wpływu na „losy przeciętnego śmiertelnika” nie zrealizowały. Jedną z nich może okazać się Totalizm czy kultura z 1938 roku, pióra młodszego od Iljina o siedem lat Zygmunta Mysłakowskiego.

$\mathrm{Na}$ podstawie tez Snydera można nabrać przekonania, iż żyjemy w czasach, w których warto tekst Iljina znowu czytać - zwłaszcza w kontrze do renesansu myślenia tym autorem. W książce z 2017 roku O tyranii. Dwadzieścia lekcji z dwudziestego wieku - krótkiej, pod względem objętości podobnej do książki Mysłakowskiego z 1938 roku - Snyder zawiera między innymi następujące lekcje (wymieniam te, które można odnaleźć także w Totalizmie czy kulturze - część z nich to niemal cytaty z Mysłakowskiego):

- nie bądź z góry posłuszny;

- strzeż się państwa jednopartyjnego;

- miej się na baczności przed organizacjami paramilitarnymi;

- wyróżniaj się;

- dbaj o język;

- bądź dociekliwy;

- chroń swoje życie prywatne;

- nasłuchuj niebezpiecznych słów.

Chciałbym zatem przedstawić wywód Mysłakowskiego z 1938 roku jako ważny dla rozumienia czasów teraźniejszych i mechanizmów społecznego sprzyjania totalizmom (to drugie zadanie niniejszego artykułu), które za Snyderem najkrócej można określić jako rozprzestrzenianie się fikcji politycznej w Rosji, Europie i Ameryce oraz powrót myślenia totalitarnego. Sądzę, że przestrojona na potrzeby opisu

${ }^{5}$ C. Miłosz: Zniewolony umyst. Paryż 1953, s. 15.

${ }^{6}$ T. Snyder: Droga do niewolności..., s. 29. 
początków XXI wieku książka Mysłakowskiego może być traktowana $\mathrm{z}$ racji na swą moc analityczną, styl niestarzejących się diagnoz czy repertuar narzędzi nazywania zjawisk co najmniej na równi ze współcześnie powstającymi komentarzami. Gdy Lech Witkowski czyta ten niewielki rozmiarami tomik, a jego autora zalicza do zasłużonych między innymi dlatego, że dokonał on przełomu paradygmatycznego Wielkiego Pokolenia polskiej pedagogiki, wyznaje: „Najważniejsze jednak jest dla mnie pokazanie trosk kulturowych Z. Mysłakowskiego, pozostających i dziś zadaniem dla nas tym większym, że nawet niedostrzeganym, a na dodatek przytłoczonym odmiennym kierunkiem dążeń tylko pozornie niemających nic wspólnego z kryzysem cywilizacyjnym. Czytajmy zatem książkę Totalizm czy kultura Z. Mysłakowskiego jako zawierającą listę niepokojów, często zaskakująco wyprzedzających czas, zarazem niosących język alarmistycznych diagnoz i dramatycznych postulatów ważnych obecnie"7. Czytajmy zatem.

\section{Totalizm czy kultura?}

Można odnieść wrażenie, że Zygmunt Mysłakowski nie zapisał w książeczce z 1938 roku zdań przypadkowych. Tym większej uwagi domagają się zawarte na jej początku cytaty w funkcji mott. Jeżeli potraktować je jako zapowiedź dominant myślowych właściwej treści, to otrzymamy następujący zestaw tez:

- społeczność buduje się z wewnątrz (Paul Natrop);

- społeczność doskonała dysponuje wieloma formami działania (André Gide);

- przyszłości nie buduje się na świecie dzisiejszym (Johann Heinrich Pestalozzi);

- gest artystyczny jest czerpaniem z głębi - o wielkości śmiałka świadczy to, czy w owej głębi uda mu się nie utonąć (Richard Dehmel).

Zatem już w geście inicjującym rozważania wskazuje autor na szkodliwość autorytarnego zarządzania społeczeństwem, przedstawia różnorodność jako istotę demokracji, pokazuje dojmujące znaczenie przeszłości dla losów przyszłych oraz docenia twórcze dynamizowanie form społecznego bycia. Oto niemal cały program książki - „niemal”, wspomniane motta poprzedzone są bowiem jeszcze znaczącą i poetycko enigmatyczną dedykacją. Powrócimy do niej jeszcze.

W pierwszej części swojej książki Mysłakowski rozważa kondycję jednostki w czasach zmieniania się form społecznych. Stwierdza, że

${ }^{7}$ L. Witkowski: Przełom dwoistości w pedagogice polskiej. Historia, teoria, krytyka. Kraków 2013, s. 282. 
postawa dociekająca jest czymś dla mas obcym. Większość jednostek stosuje jedynie utarte szablony poznawcze, które co najwyżej po ich opanowaniu na wysokim poziomie mogą zdać się czymś żywym, samorzutnym. Generalnie myślenie wykraczające poza bezpośrednią życiową konieczność okazuje się swego rodzaju „biologicznym luksusem"8 i jest potrzebą jedynie wąskiej grupy ludzi. Jeżeli w myśleniu pojawi się jakaś racjonalność i rzeczowość, to w warstwach świeżych, bez tradycji, ale i tutaj z czasem ulega przeterminowaniu. W tym kontekście swoją współczesność uznaje autor za cechującą się atrofią dociekliwości. Uważa, że ów stan pogłębia się wręcz gwałtownie, czego znakiem jest przede wszystkim wzbieranie kolektywizmów i totalizmów kosztem ustępujących demokracji. By powstał opór wobec tych tendencji, konieczny jest społeczny kapitał postaw dociekliwości i racjonalności. W tym względzie jednak masy poniosły bankructwo - są łatwowierne, bezbronne w obliczu propagandy i ślepe na kompromitację głoszonych przez nią haseł.

Źródeł dramatyzmu, który dostrzega Mysłakowski w kształcie i przeobrażeniach swojej współczesności, należałoby szukać z jednej strony $\mathrm{w}$ przemianach systemów politycznych, tendencji ideowych i mechanizmów rządzących masami, natomiast z drugiej w tym, co stanowi charakter funkcjonowania jednostek jako takich. W tym drugim względzie autor dokonuje analizy możliwych typów psychicznych, które rozważa na płaszczyźnie przemian społecznych (do typologii tej przyjdzie tu jeszcze powrócić). Stwierdza: „żywioł psychiczny [...] poszukuje sobie zawsze formy" ${ }^{9}$, ta zaś jest tym lepsza, im bardziej przemyślana i adekwatna do treści. Korzystne jest także istnienie szerokiego spektrum form alternatywnych, ponieważ bogactwo możliwości wzmaga swobodę wyrażania się jednostki. Pula narzędzi wyrazu jednostki jest więc określana w sposób społecznie zobiektywizowany. Mysłakowski dokonuje spięcia jednostkowości z bytem społecznym. Kiedy więc pisze: „Chcąc żyć, musimy żyć zbiorowo”" nie ma na myśli roztopienia jednostki w jednolitej zbiorowości, lecz autonomiczność w sensie możliwości poruszania się we względnie szerokiej, uznanej społecznie puli form ekspresji.

Kondycja jednostki zależy zatem od możliwości wyrazu ${ }^{11}$ które są jej fundowane przez społeczne zorganizowanie. Czym owo zorgani-

\footnotetext{
${ }^{8}$ Z. Mysłakowski: Totalizm czy kultura..., s. 11.

9 Ibidem, s. 18.

10 Ibidem, s. 19.

11 „Dopóki nie stworzona zostanie właściwa forma, żywioł pozostanie zamknięty w jakimś świecie odrębnym, gdzie może być wszystkim, lecz gdzie jest jeszcze niczym”. Ibidem, s. 18-19.
} 
zowanie jest gwarantowane? Niemal niczym. Ów „świat pojęć o rzeczywistości, form artystycznych, idei prawnych i politycznych, nie jest niczym więcej zagwarantowany, jak tym tylko, że utrzymuje się własną mocą, jakąś inercją, tak długo, dopóki nic go nie zakwestionuje, dopóki w polu zetknięcia się żywiołu psychicznego jednostek z tym, co nim nie jest, nie nastąpią jakieś wstrząsy, jakieś nowe spięcia, nie powstaną jakieś nowe formy"12. Należy jednak mieć tu na względzie, że im forma bardziej doskonała, adekwatna, specjalistyczna, tym bardziej więzi i ogranicza, bo kumuluje wspomniane inercyjne tendencje ${ }^{13}$. Stąd istotna jest troska o zdolność jednostki do uświadomienia sobie uwiązania formą, tkwienia w koleinach wyrazu.

Aby rozważyć potencjał jednostki w rozpoznaniu uwikłania w formę, Mysłakowski wprowadza stopnie uświadomienia ducha ludzkiego. Otrzymujemy tą drogą trzyelementową koncepcję typów psychicznych. Stopień najwyższy to stopień wyobraźni twórczej, stopień nowatorów, zdolnych do tworzenia form nieprzewidzialnych; realizuje się w świadomości artystycznej, moralistycznej, politycznej, naukowej. Stopień niższy charakteryzuje ludzi rutyn indywidualnych i zbiorowych, żyjących konwencjonalnie, bez aspirowania do tworzenia nowych form i wartości. Stopień najniższy, zdeterminowany przez dyktat instynktów, automatyzmów, emocji, cechuje ludzi podświadomości.

Lektura książki Totalizm czy kultura może zaskoczyć fragmentami, w których wywód grawituje ku rozważaniom psychologicznym - tam, gdzie otwiera zagadnienia o charakterze ideowym, politycznym, cywilizacyjnym. To fragmenty analitycznie szczególnie zyskowne. Mysłakowski wykonuje jednak także gest odwrotny. Po wyłożeniu stopni uświadomienia ducha ludzkiego (nawiązuje tu między innymi do kategorii monady z koncepcji Gottfrieda Wilhelma Leibniza) każdy z nich rozważa w kontekście szerokiego horyzontu przemian cywilizacyjnych. Stwierdza więc, że w epokach stabilizacji najlepiej wiedzie się ludziom typu konwencjonalnego, których przejmuje niepokojem czas burzliwych przemian. Los intelektualistów, którzy w okresie stabilizacji budzą nienawiść, w czasie burzliwym jest bardziej zróżnicowany - jedni dochodzą do głosu, inni giną. Stosunkowo najlepiej w czasach niepokoju wiedzie się jednostkom typu instynktowego. Wszelkie rewolucje wydobywają ich z nizin, a z tymi jednostkami na powierzchnię wyłania się „niechęć do wszystkiego, co twórcze i indywidualne, ich apoteozowanie gminności, wodzostwa, sentymentu zbio-

12 Ibidem, s. 20.

${ }^{13}$ Napisze Mysłakowski na bardziej zaawansowanym etapie wywodu, że istnieje mnóstwo przejawów finezyjnej formalnie akademickiej sztuki, które okazują się zupełnie nieinteresujące, bo bezduszne (ibidem, s. 48). 
rowego, pławienia się w kolektywnym entuzjazmie"14. I dalej o typie ludzi podświadomości: „Uwielbianie, ubóstwianie hordy jest najgłębszą ich mądrością i religią"15. We fragmencie tym Mysłakowski stawia surowe tezy: „to głosiciele świętej wojny, dla samej wojny, szowinizmu, antysemityzmu" ${ }^{16}$; a w kwestii ostatniej dodaje: "Jeśliby nie było żydostwa, trzeba by coś wymyślić, żeby móc skierować nagromadzoną wrogość mas, tłumioną w zwykłych warunkach przez cywilizację, przeciw komuś lub czemuś"17. Wywoływanie antagonizmów wspólnotowych staje się także politycznym interesem.

Swoje czasy określa autor jako sprzyjające tworzeniu się wielkich wspólnot. Efektem tej tendencji jest mechanizm upraszczania faktu społecznego, przekształcania go w mit społeczny drogą „urabiania” legendy. Mysłakowski przesuwa soczewkę uwagi ze społeczeństwa na kategorię narodu. To w jej ramach dochodzi do splotu tego, co jednostkowe (psychiczne), i tego, co zbiorowe: przynależność narodowa jest efektem asymilacji psychospołecznej. Nie jest w tej kwestii decydujące podłoże biologiczne, lecz „wychowanie we wspólnocie i to tajemnicze powinowactwo wewnętrzne: przyzwolenie na nią całkowicie i bez żadnych zastrzeżeń"18. Jednocześnie naród jest bytem historycznym, dlatego też dotkliwa okazuje się przerwa w jego tradycji (zachowań, postawy życiowej, nawyków, typów emocjonalnych). Właściwie dochodzi wówczas do wyrzucenia danego historycznego narodu poza granice - $\mathrm{w}$ inną tradycję lub $\mathrm{w}$ „masę bezkształtną, zorganizowaną na niższych szczeblach" ${ }^{\prime \prime}$. Czy takie wydziedziczenie to katastrofa dla zbiorowości? Niekoniecznie.

Wieczność jest horyzontem również dla poszczególnych indywidualności - człowiek istnieje także w rzeczywistości pozahumanistycznej. I ten właśnie stan pozwala mu na przezwyciężanie form, w których zamyka go świadomość, tradycja, kultura: „Dzięki tej grze antagonistycznych sił - stwierdza Mysłakowski - człowiek zbiorowy nie jest niewolnikiem raz stworzonych przez siebie tworów, lecz ich panem"20. Odtąd zaczyna Mysłakowski rozważać dynamiczność i rutyniczność form zbiorowości. Pokazuje, że niejednokrotnie instytucje czcigodne, dostojne dzięki swej tradycji, ale też doskonałe w wymiarze formalno-organizacyjnym są czymś anachronicznym. Instytucje te są jak pusty

14 Z. Mysłakowski: Totalizm czy kultura..., s. 27-28.

15 Ibidem, s. 28.

${ }^{16}$ Ibidem.

${ }^{17}$ Ibidem.

18 Ibidem, s. 36.

19 Ibidem, s. 43.

20 Ibidem, s. 45. 
orzech, którego twardość skorupy podtrzymuje złudzenie, że w środku jest coś żywego. Gdyby obrazowo ująć historyczne przemiany form zbiorowości, można by je porównać z ruchem wahadła, którego maksymalnym wychyleniem są z jednej strony indywidualistyczne, z drugiej kolektywistyczne stany rzeczywistości społecznej. Ruch ten polegałby na dążeniu do wolności - a więc do ryzyka i odpowiedzialności - i odchodzeniu od niej, gdy owo ryzyko i odpowiedzialność za wybory stają się niedogodnym obciążeniem. Oto i napęd owego wahadła: gdy człowiek nie może znieść dłużej poczucia związanej z indywidualizacją „winy metafizycznej”21, ulega pragnieniu, by oprzeć się na wspólnocie, szukać ulgi w odpowiedzialności zbiorowej.

Jak się ma owo naprzemienne pulsowanie indywidualizmu i kolektywizmu do trwania narodu? Jednostka niezależnie od własnego interesu może czuć się związana z jakąś „sprawą”, czuć potrzebę wzmacniającego ją samą opierania się na czymś trwałym - na idei narodu właśnie. Jego istnienie jest procesualne, co wiąże się z doniosłą rolą tradycji. Jednostka będzie przynależała do tej tradycji w takim stopniu, w jakim wewnętrznie przyjmie ją jako coś swojego. To wewnętrzne związanie ze wspólnotą sprawia jednocześnie, że jednostka nie jest już sobą, nie jest także wolna w swym sądzie ani nie może przyjąć w pełni racjonalnej postawy. Zresztą już sama tradycja, jak pisze Mysłakowski, „to pewien dobór faktów, dokonany nie pod kątem widzenia poznawczym, lecz na podstawie logiki uczuć"22.

Wszelako celem istnienia narodu nie jest upodobnienie się do siebie wszystkich jednostek. Wspólnota jest raczej jak utwór symfoniczny uporządkowanie różnych elementów, które wobec siebie są zarówno w harmonii, jak i w dysharmonii. To całość tworzona z różnorodności i wyzwalanych w niej napięć. Ma to swoje konsekwencje dla statusu narodowych świętości - tylko słabi wewnętrznie potrzebują jednogłośnego schlebiania, pustych frazesów czy wręcz kłamstwa. A to dlatego, że miarą żywotności kultury jest zakres swobody kwestionowania, jaki ta kultura dopuszcza. Zresztą zakłamanie ubocznie - a przecież przemożnie w konsekwencjach - wywołuje brak zdolności wiary w cokolwiek. Zygmunt Mysłakowski uznaje, że cenniejszy dla przyszłości wspólnoty jest jeden człowiek wolny i oddany, broniący spraw mocą własnego przekonania i biorący na siebie ryzyko, niż krzyki propagandy.

W ostatniej części Totalizmu czy kultury jej autor pyta o możliwość tworzenia wspólnoty wewnętrznej narodu. Widzi tu dwie drogi, które ujawniają się także w tytułowej frazie książki. Pierwsza to „samorzut-

\footnotetext{
${ }^{21}$ Ibidem, s. 52 .

${ }^{22}$ Ibidem, s. 57.
} 
nie wyrównująca się kultura"23, oparta na naśladownictwie, perswazji, dyskusji, na twórczych dziełach artystów, uczonych, publicystów, filozofów, na rzemiośle, obyczaju, tradycji. Druga to droga propagandy - haseł, wartości, form bytowania. „Trzeba uprzytomnić sobie grozę tego faktu - wskazuje Mysłakowski - że w pewnych warunkach [...] wystarczy trzy miesiące systematycznego kłamstwa na łamach popularnego dziennika, żeby zasugerować masie czytelników [...] - wszystko, dosłownie wszystko"24.

Żadna megalomania jednostki nie mogłaby jednak nigdy narzucić się zbiorowości, gdyby ta nie czuła potrzeby zwierzchności, potrzeby wodza. „Czasy nasze - pisze Mysłakowski - charakteryzuje ta potrzeba być może epoka, która nadchodzi, będzie od ich imienia nazwana"25. Nie chodzi tu wszakże o tęsknotę za figurą herosa - to raczej psychologiczna rewolta stłumionych kompleksów podświadomych. Jest bowiem czasem tak, że człowiek pomimo wieku nie dojrzewa, staje się tchórzliwy, nie nabiera odwagi cywilnej, nie poddaje się próbie, lecz ukrywa w krętactwie i stadności. Lekceważy naukę i intelekt, socjalizm i demokrację, a preferuje wpatrywanie się w "ducha dziejów" i „ględzenie o miłości" ${ }^{26}$. Oto jest materiał na wodza, który grasować będzie na kulturze za pośrednictwem wulgarnego dobierania idei. Oto Kaliban mówiący do Kalibanów; wódz, który nie tworzy niczego poza naciskiem propagandy i trafia na masy sprzyjające przywództwu duchowemu „kieszonkowego formatu”, krzewiącemu kulturę awanturników żywiących się atmosferą katastrofy, barbarzyństwa niedojrzałych mas, jedności wbrew różnorodności. Tak oto Zygmunt Mysłakowski określa swoją teraźniejszość: „Przeciwieństwo wszystkiego, co dostojne, wszystka lichota, brak dobrego smaku, wszelka wulgarność - zjednoczyło się i maszeruje triumfalnie" ${ }^{27}$. Antidotum? Powrót do demokracji społecznej, ulepszonej. Jaką drogą?

Gdy ukazała się książka Totalizm czy kultura, Józef Piłsudski nie żył już od trzech lat. Jego legenda tym żywiej jednak rosła. Oto wspomniana już tutaj dedykacja, którą Zygmunt Mysłakowski opatruje swoją publikację: „Cieniowi tego, który, wzywając naród do wielkości, wodzem niewolników być nie chciał. - Cieniowi tego, który niegdyś stoczył z sobą walkę o najgłębszą prawdę swego narodu - jak Jakub z aniołem - i odszedł, unosząc w sobie rzeczy niedopowiedziane - byśmy

\footnotetext{
23 Ibidem, s. 62.

24 Ibidem, s. 66.

25 Ibidem, s. 67.

26 Ibidem, s. 75.

27 Ibidem, s. 68.
} 
mogli być jego współpracownikami, a nie spadkobiercami"28. O kim tu mowa - wątpliwości być nie mogło, wszelako Marszałek przywołany jest jeszcze w ostatnich zdaniach książki: „Prawdziwi myśliciele, do których zaliczam Marszałka Piłsudskiego, gromiąc demokrację źle zorganizowaną, cofali się jednak przed jej zniszczeniem od podstaw. Byli prawdopodobnie świadomi, że demokracja jest szkołą uspołecznienia mas i że lepszego środka do tego celu nie znaleziono. / Totalizm nim nie jest. Niszcząc motywy, które prowadzą człowieka do zainteresowań »rzeczą społeczną", grasować on może jakiś czas na kapitale dawniej wytworzonych wartości, nowych jednak nie wytworzy. W rezultacie proces ten wyrazić się może $w$ głębokim zdziczeniu mas" ${ }^{29}$. W ten sposób domknął Mysłakowski klamrę narracyjną otwartą dedykacją. Owszem, nazwisko Piłsudskiego pada w tekście ledwie raz, na ostatniej stronie, lecz jego postać, jak sądzę, sekunduje całej treści. Motyw ten wymaga rozważenia - a to przenosi nas do części analitycznej niniejszego tekstu ${ }^{30}$.

\section{Likwidacja Europy}

\section{Europa}

Powróćmy do jednego z, jak się zdaje, ważniejszych zdań Totalizmu czy kultury. Zygmunt Mysłakowski stwierdza w nim, iż za sprawą gry „antagonistycznych sił, kulturotwórczej i kulturozachowawczej, człowiek zbiorowy ujęty jako całość, nie jest niewolnikiem raz stworzo-

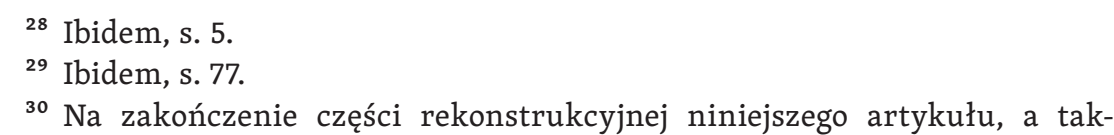
że w odpowiedzi na recenzencką podpowiedź chciałbym zwrócić uwagę na jeszcze jedną kwestię. Otóż ważna i interpretacyjnie przydatna dla odczytań przesłania książki Mysłakowskiego może okazać się analiza charakteru norm, które uznaje autor za istotne dla przemian zbiorowości. Opisując ów charakter, warto odwołać się do rozróżnienia na normy przystosowania i normy etyczne (podział ten można dostrzec już w samym tytule książki). Zawarta w Totalizmie czy kulturze koncepcja jednostki, definiowana w znacznej mierze przez dokonywanie ekspresji za pomocą dostępnych jednostce form społecznych, kazałaby widzieć tu wyłącznie dyktat norm przystosowania, ale tylko wówczas, gdy nie zauważymy, że Mysłakowski dopomina się o maksymalizację dostępnej puli tychże społecznych form działania i uzależnia od jej różnorodności zdrowie demokracji. Ponadto bez zdolności prowadzenia autentycznej refleksji etycznej najpewniej nie widział Mysłakowski szansy, by człowiek mógł przynależeć do nowatorów, jednostek realizujących się w tworzeniu form nieprzewidzianych i (tym samym) aktywności moralistycznej. 
nych przez siebie tworów, lecz ich panem" ${ }^{31}$. Lech Witkowski widzi $\mathrm{w}$ tym akcencie jeden z przejawów paradygmatycznego zorientowania Mysłakowskiego w ramach przełomu dwoistości, tu realizującego się w dostrzeżeniu nieredukowalnego napięcia między jednoczesnością potrzeby zakorzenienia a przełamaniem stagnacji w życiu społecznym $^{32}$. Sądzę, że owo napięcie jest również cechą cywilizacyjną realizowaną w ruchu oscylacji między tradycją i unowocześnieniem, że Mysłakowski definiuje tu także duchową wspólnotę Europy.

Leszek Kołakowski nazywa rzecz podobnie, gdy do tematu europejskości odnosi się już bezpośrednio. Opisując osobliwości ducha europejskiego, wskazuje na jego „zdolność do wyrywania się z własnego zamknięcia, zdolność do patrzenia na samego siebie oczami innych (bardzo charakterystyczną w literaturze oświeceniowej), do samokrytycznego dystansu, a więc do odmowy zakończonej i trwałej samoidentyfikacji”; dodaje: „ta cywilizacja umiała mimo potężnych oporów wyzwolić ducha tolerancji, uznać rozmaitość za szczególną wartość życia, stymulować ducha wynalazczości, a zarazem sceptyczną nieufność"33. Jasne, że perturbacje dziejowe czyniły ów stopień realizacji tego projektu mniej lub bardziej zaawansowanym. W tym kontekście okresem, za którym najbardziej można tęsknić, jest czas szesnasto-, siedemnastowiecznej wspólnoty zwanej respublica literaria. Kołakowski podkreśla, że w tym duchu Europa - właśnie jako „terytorium duchowe” stanowiona była przez rozmiłowane w klasycznej łacinie, znające się i czytające wzajem grono uczonych. W Totalizmie czy kulturze Mysłakowski poniekąd tłumaczy możliwość pojawienia się takiej wspólnoty, kiedy stwierdza, iż ,jest w każdej warstwie pewna liczba, niewielka na pewno, jednostek, dla których to »myślenie ponad potrzebę« staje się samo potrzebą”; i zaraz dodaje: „Spośród nich wyrastają nowatorzy”34.

Znamienne, że w przytaczanym tu fragmencie Kołakowski używa czasu przeszłego. Nie sposób odnaleźć u początków XXI wieku wyraźnej analogii do republica literaria. Zresztą etos ten nie był także udziałem twórców i twórczyń międzywojennej polskiej myśli pedagogicznej w tym sensie, że jednym z powodów nieuświadomienia sobie przełomu paradygmatycznego, który się wówczas dokonywał, przez osoby go tworzące było to, że nie dość się one nawzajem czytały ${ }^{35}$.

31 Ibidem, s. 45

32 Por. L. Witkowski: Przełom dwoistości w pedagogice polskiej..., s. 283.

${ }^{33}$ L. Kołakowski: Niepewność epoki demokracji. Wybór i słowo wstępne Z. Mentzel. Kraków 2014, s. 228.

34 Z. Mysłakowski: Totalizm czy kultura..., s. 12.

35 Por. L. Witkowski: Przełom dwoistości w pedagogice polskiej... 


\section{Zła demokracja}

Ogólny niepokój społeczny okresu międzywojennego sprawia, że Zygmunt Mysłakowski u schyłku lat trzydziestych XX wieku stwierdza: „Wstąpiliśmy w okres coraz bardziej przyspieszonej, coraz bardziej gwałtownej »likwidacji Europy «"36. W tym samym roku, w którym słowa te zostały wydane, Ludwik Chmaj publikuje napisaną z rozmachem syntezę Kierunki i prądy pedagogiki wspótczesnej. Jej pierwszy rozdział także zawiera opis epoki autorowi współczesnej. Współbrzmią te analizy z wywodem Mysłakowskiego choćby w dostrzeganych przez obydwu pisarzy tendencjach ujednolicających społeczeństwo z podkreśleniem znaczenia środków masowego przekazu. Chmaj w tym względzie kładzie większy nacisk na moralne tego konsekwencje. Różnorodne wzory obyczajowe i moralne ideały, wystawione na siebie nawzajem, tracą wartość; co więcej: „To ścieranie się w dobie obecnej różnych norm obyczajowych osłabia coraz skuteczniej znaczenie wszelkich powag i autorytetów" ${ }^{37}$. Gdy Mysłakowski pisze o gwałtowności przemian form społecznych, które dokonują się na jego oczach, w tym samym czasie dwa lata od niego młodszy Ludwik Chmaj stwierdza: „Gorączkowość i niepokój we wszystkich dziedzinach życia współczesnego potęguje rosnąca z dnia na dzień zmienność i płynność cywilizacji"38. W tych też międzynarodowych tendencjach dopatruje się autor Kierunków i prądów pedagogiki wspótczesnej źródeł nacjonalizmu, a także rozszerzania działań państwa i umacniania jego przewagi. Jak pisze dalej: „Rozrost funkcyj państwowych sprowadził w następstwie ograniczenie, a nawet zniesienie, jak w państwach totalnych, wolności słowa, swobody ruchu i zrzeszania się jednostek, a nawet całkowite podporzadkowanie dążeń jednostkowych woli i celom państwa"39. Tak też opis niepokoju czwartej dekady XX wieku ukazany przez Mysłakowskiego wzbiera jeszcze wypowiedziany tu w dwugłosie z Chmajem, który swe czasy uznaje za epokę wręcz schyłkową ${ }^{40}$.

Wszelako autor Kierunków i prądów pedagogiki współczesnej we wstępnych dla swej pracy rozważaniach zamieszcza zdanie, które dotąd zbieżne poglądy obydwu pisarzy wprowadza w poważny wzajemny dysonans. Wskazana zostaje tu rzecz następująca: „Owe przemiany życia obyczajowego przyśpiesza i pogłębia potężniejący we wszystkich

\footnotetext{
${ }^{36}$ Z. Mysłakowski: Totalizm czy kultura..., s. 13-14.

${ }^{37}$ L. Chmaj: Kierunki i prądy pedagogiki współczesnej. Warszawa-Wilno 1938, s. 10.

${ }^{38}$ Ibidem.

${ }^{39}$ Ibidem, s. 11.

${ }^{40}$ Por. ibidem, s. 22.
} 
krajach prąd demokratyzacji, który zaciera różnice między typami i grupami społecznymi i upodabnia je i zbliża do siebie. Wynikiem tych przemian jest widoczne obniżenie się ogólnego poziomu kulturalnego"41. Zauważmy więc, że dla Mysłakowskiego osiowa w myśleniu o demokracji idea różnorodności wewnętrznej zbiorowości tu zastąpiona jest przez mechanizm odwrotny. Jednocześnie wcześniejsze wypowiedzi Chmaja sugerują, że nie czyni on kroku w kierunku totalizmu, nie tęskni za systemem bagatelizującym wolność jednostki - także dlatego, że we wspomnianej tu syntezie wydaje się skłaniać ku pedagogice humanistycznej doceniającej autonomię żywiącej się kulturą jednostki. Chodzi więc o jakąś złą demokrację? Źle pomyślaną?

Sens całej wypowiedzi Chmaja zdaje się to wskazywać. Nie sentymentalizuje demokracji także Zygmunt Mysłakowski. O złej realizacji idei demokratycznych mówi wprost, gdy stwierdza, że choć prawdziwi myśliciele atakowali „demokrację źle zorganizowaną" ${ }^{42}$, cofali się przed jej zniszczeniem od podstaw. Dla Mysłakowskiego takim myślicielem był Józef Piłsudski - i to jedyna postać, którą w tym kontekście autor wskazuje. Tym samym gruntowna krytyka totalizmu dokonana jest w tekście jednocześnie z afirmacją postaci, która gromi demokrację, zatrzymując się w przedsionku jej zniszczenia. Dostrzeżmy to napięcie.

Mysłakowski w swojej teorii przemian wspólnot splata bycie psychiczne i społeczne człowieka. Rozważa także program pozytywny wynikły z tego splotu. Pojawia się w jego ramach możliwość zaistnienia myślących, twórczych zbiorowości, kształtujących jednostki. Tę opcję autor Totalizmu czy kultury wydaje się jednak porzucać w horyzoncie możliwości własnych czasów. Pisze między innymi o sobie współczesnych: „Dzieje się tak, jak gdyby człowiek zbiorowy stworzywszy sobie kulturę potężnym wysiłkiem najlepszych, sam uznał się za niedojrzałego do niej, wyparł się swego dzieła i oświadczył, że nie mogąc żyć w klimacie wyżyny, woli zejść na moczary" ${ }^{43}$. Wobec degradacji mas rozważyć więc należy według Mysłakowskiego inną drogę ulepszenia form bycia wspólnot. Podążając nią, należałoby zadać pytanie o możliwość pojawienia się postaci, której psychologiczne przymioty umożliwią jej przemożny wpływ na życie zbiorowości i wydobycie jej ze stanów niskiego funkcjonowania. Wspomnijmy kulturotwórczą dla wspólnoty rolę nowatorów, o których już tu była mowa. To grupa dostarczająca nowych form społecznego bycia - dynamizuje je i poszerza ich pulę, wzbogaca sieć ścieżek ekspresji jednostek. Sęk w tym, że - jak wynika z wywodu Mysłakowskiego - postać wybitna wypatrywana

\footnotetext{
${ }^{41}$ Ibidem, s. 11.

42 Z. Mysłakowski: Totalizm czy kultura..., s. 77.

${ }^{43}$ Ibidem, s. 37.
} 
przez masy rodzi widmo przyszłej dyktatury. Wystarczająco wyraźnie autor opisał ten mechanizm, deprecjonująco go wypunktował - nawet w trybie prześmiewczym. Zdaje się, że oto znaleźliśmy się między młotem i kowadłem. Czy na pewno? Odpowiedzi na to pytanie w dalszym biegu rozważań poszukamy między innymi w tekście - nomen omen Grzegorza Kowala.

Analiza znaczenia, jakie przypisuje jednostce wybitnej Mysłakowski, jest istotna dla odczytania całej omawianej tu książki. Jak się też okaże, na planie tak prowadzonych rozważań ukazać można również meandry przechodzenia totalizmu w demokrację i odwrotnie. Zagadnieniu poświęcę kilka kolejnych akapitów także dlatego, że Mysłakowski na planie społeczno-politycznych rozważań teoretyzuje na temat znaczenia wodzów czy nowatorów, a przy tym sam siebie lokalizuje w polu społecznego działania Józefa Piłsudskiego. To merytorycznie ważny kontekst Totalizmu czy kultury - warto się mu przyjrzeć, gdy chcemy odczytać sens całej książki ${ }^{44}$.

\section{Marszałek}

W 1938 roku, gdy wydana została książka Totalizm czy kultura, pogrobowy wpływ polityczny Józefa Piłsudskiego był wciąż przemożny. Także kosztowny, jak pokazywał to Bogdan Nawroczyński: „W naszym życiu politycznym nastąpił zastój. Spowodowali go sprawujący władzę epigonowie Marszałka. Świat dokoła Polski szybko się zmieniał, oni zaś z uporem kontynuowali politykę Marszałka i nie dopuszczali do żadnej zmiany" ${ }^{45}$. Polityczne znaczenie Piłsudskiego trwało do czasu „zresetowania" polityki przez wojnę i okoliczności nowego układu powojennego. Pod koniec lat trzydziestych nawet sam pogrzeb Marszałka musiał pozostawać w pamięci społeczeństwa. Grzegorz Kowal w książce Anatomia kulturowej legendy nazywa to wydarzenie „bodaj największym

${ }^{44}$ Status jednostki dysponującej władzą jest w kontekście rozważania totalizmu i demokracji jednym z zagadnień węzłowych - a dla prowadzonych tu rozważań tym ważniejszym, że traktująca de facto o dylemacie formy władzy książka Mysłakowskiego jest dedykowana właśnie pamięci polityka, który szerokim zakresem władzy dysponował. Stąd kontekst postaci Józefa Piłsudskiego w niniejszym artykule dość mocno został rozwinięty. Zawsze jednak był to wyłącznie kontekst odczytania książki Mysłakowskiego, motywowany próbą odsłonięcia okoliczności i aury jej powstania.

45 B. Nawroczyński: Oddech myśli. Archiwalia główne. Wybór, komentarze i red. naukowa L. Witkowski. Kraków 2020, s. 343. 
spektaklem w historii naszego kraju"46. Jak pisze o Piłsudskim: „śmierć nie zatrzymała jego pochodu ku wielkości" ${ }^{\prime 7}$.

W Weberowskiej koncepcji typów legitymizacji władzy Piłsudskiego wpisuje się w model charyzmatyczny (pozostałe to oparty na prawie oraz oparty na tradycji ${ }^{48}$ ), stąd wyobrażenie o preferowanym systemie politycznym przylegało silniej do jego postaci, było motywowane jego postawą, a ta od idei demokratycznych odbiegała. Grzegorz Kowal określa charakter ustroju demokratycznego podobnie, jak to czyni Mysłakowski - wskazuje, iż siła tego systemu „zasadza się na istnieniu opozycji parlamentarnej, odmiennych, lecz tworzących nierozerwalną całość poglądach, wizjach i pomysłach na rozwiązywanie problemów"49. I właśnie tego zdaniem Kowala Piłsudski nie zrozumiał. Dedykacja dla Marszałka i finał Totalizmu czy kultury - eseju broniącego podstaw demokracji w czasach wzmagających fal totalizmu - sugeruje, że Mysłakowski tej sprzeczności nie widzi.

Opowieść o Józefie Piłsudskim we wspomnianej książce Grzegorza Kowala zapośredniczona jest między innymi przez lekturę kanonu tekstów rozważających postać Marszałka. Na ich podstawie i w toku własnych analiz autor dokonuje ocen na polach analogicznych pod względem tematu do tych, o których pisze Mysłakowski, gdy rozważa kategorię wodzostwa. Efekt analiz Kowala wydaje się wykluczać Piłsudskiego z demokratycznego programu, który w rozważaniach Mysłakowskiego jest projektem pozytywnym. Zwróćmy w tym kontekście uwagę na kilka składających się na taki stan rzeczy aspektów.

Autor Totalizmu czy kultury chciał społeczeństwa pozwalającego na swobodę wyrazu i dlatego mnożącego możliwe formy ekspresji, chciał systemu, który nie jest oparty na idei jedności wbrew różnorodności. Tymczasem stwierdza Kowal: „marszałek nie mógł znieść charakterystycznej dla demokracji odmienności opinii i gotowości do ich obrony, a dawni współtowarzysze, ludzie o indywidualnych poglądach i silnej woli, nie potrafili się odnaleźć w roli klakierów"50. Dodaje również, że właściwą konsekwencją „depczącego demokrację” przewrotu majowego może być Trybunał Stanu, a nie dołączenie do panteonu władców pochowanych na Wawelu. Zresztą Piłsudski miał notorycznie stosować „taktykę kompromitowania ludzi ambitnych i autonomicznych,

${ }^{46}$ G. Kowal: Anatomia kulturowej legendy. Niżyński, Gründgens, Dönhoff, Piłsudski. Kraków 2014, s. 330.

47 Ibidem, s. 342.

${ }^{48}$ Por. M. Weber: Gospodarka i społeczeństwo. Zarys socjologii rozumiejącej. Przeł. i wstępem opatrzyła D. Lachowska. Warszawa 2002.

${ }^{49}$ G. Kowal: Anatomia kulturowej legendy..., s. 337.

50 Ibidem, s. 329. 
dla niego wyjątkowo niewygodnych" ${ }^{51}$. Negację wielogłosu realizował Marszałek przez stosowanie inwektyw do „eliminowania, dyscyplinowania i karcenia nieposłusznych" ${ }^{22}$. Wspomnijmy tu uwagi Mysłakowskiego o symptomatycznym dla totalizujących tendencji obniżaniu poziomu języka debat, ale także ważne komentarze dotyczące przedstawiania przeszłości w kontekście wodzowskich nadużyć. Grzegorz Kowal odnosi się również do tej drugiej kwestii. Stwierdza, że Marszałek do historiografii miał stosunek dość specyficzny. Zakładał, że uwydatniane są momenty wielkości, a usuwane opisy odbrązawiającej naród lekkomyślności. W efekcie: „Pośrednio praca nad historycznymi źródłami dała Piłsudskiemu oręż w walce o »rząd dusz«. Aż do śmierci służyła mu - jako swoista wunderwaffe - do osłabiania parlamentarnej opozycji i eliminowania politycznych oponentów" ${ }^{33}$. Tak sprofilowana wyobraźnia historyczna Marszałka musiała wywołać i to, że: „Nikt jak on nie opanował sztuki autokreacji. Dbał o swój wizerunek wielopłaszczyznowo i kompleksowo, pieczołowicie troszczył się zarówno o detale [...], jak i sprawy uniwersalne"54. Dziełem tej sztuki była choćby niepisana umowa między Piłsudskim a narodem. $Z$ jednej strony bowiem, pisze Kowal, „Nie istnieje bodaj jedna wypowiedź marszałka, w której przyznałby się do jakiegokolwiek błędu. Jego politycznej indolencji winny był zawsze leniwy, zidiociały i skorumpowany naród"55, $\mathrm{z}$ drugiej naród traktował te inwektywy jako wymierzone przeciwko bliżej nieokreślonym środowiskom, organy administracji zaś wspierały Piłsudskiego w budowaniu jego własnej legendy.

Sęk w tym, że perspektywa, którą uruchamia Grzegorz Kowal, jest możliwa do pomyślenia dopiero z pozycji historycznego dystansu. Historiografia zwykła preferować szkice czynione grubszą kreską, częściej niż w opisach współczesności stosować definitywne kwantyfikatory. Stąd teraźniejszość paradoksalnie wydaje się bardziej złożona niż każda przeszłość, choć ta ostatnia przecież więcej czasu obejmuje. My jednak, jeżeli czytamy Mysłakowskiego, to w spięciu z myśleniem o naszych czasach. Należałoby więc postarać się o większe zniuansowanie rozważań, dostrzec zamglenia i cienie.

\footnotetext{
${ }^{51}$ Ibidem, s. 328.

52 Ibidem.

53 Ibidem, s. 327.

54 Ibidem, s. 331.

${ }^{55}$ Ibidem, s. 336-337.
} 


\section{Cienie i opary}

Czy Mysłakowski ulegał rozgrzeszającej antydemokratyczne gesty legendzie Marszałka? Kowal stawia tezę, że Polacy „wdychają jej opary”, że są na nią skazani. Porównuje tę legendę do czadu, gdy opisuje jej działanie: „Preferowane przez niektórych krytyków pojęcie czadu (zamiast legendy) wydaje się o tyle zasadne, że czad przenika do organizmu ludzkiego niepostrzeżenie, zwany jest cichym zabójcą" ${ }^{27}$. I zaraz potem dodaje za Nietzschem: „człowiek staje się najbardziej plastyczny pod wpływem anonimowych i niewidzialnych sił"58. W 1944 roku Julian Tuwim pisał: „Im więcej zastanawiam się nad zdarzeniami i duchem tego okresu - okresu, w którym Piłsudski jawnie lub skrycie dominował - tym większe ogarnia mnie zdumienie, że my, współcześni, daliśmy się tak odurzyć i zaczadzić »romantycznym fluidem«, jakim Piłsudski promieniował. Przyznaję otwarcie, że i ja przez dłuższy czas należałem do zaczadzonych" ${ }^{59}$. Tuwim zastanawia się nad powodami tak przemożnego wpływu i wskazuje tu oszołomienie niepodległością, pochopne przyjmowanie przez jego pokolenie rozmaitych fałszów historycznych, ciążący mistycyzm i balast poezji, z których snuli Polacy poczucie o własnej dziejowej misji ${ }^{60}$. Grzegorz Kowal także wskazuje na ów historyczny kontekst: „Piłsudski i jego legenda mogli rosnąć w siłę, bo sprzyjało temu duchowe podglebie epoki, na którą składały się m.in. zwrot ku romantyzmowi, koncepcja nadczłowieka Nietzschego, aktywność kowala u Staffa, idea czynu Brzozowskiego. Wszystko obracało się wokół silnej i przepojonej energią jednostki, indywidualności wrastającej ponad przeciętność"61. W tym sensie Zygmunt Mysłakowski wydaje się synem własnej epoki. Kiedy w książce rozważa potencjalną jej nazwę, spodziewa się, że będzie ona pochodziła od imienia wodza, który ujmie masy. Z oddalenia historycznego wiemy, że czasy te często są nazwane od nazwiska architekta „cudu nad Wisłą"62.

Przypomnijmy: koniec książki Mysłakowskiego sugeruje, że Piłsudski gromiąc demokrację, krytykował jej źle zorganizowaną formę i nie mierzył w przekreślenie samej idei tego systemu. Autor zatem w posta-

\footnotetext{
${ }^{56}$ Ibidem, s. 330.

${ }^{57}$ Ibidem.

58 Ibidem.

59 List Juliana Tuwima do Tadeusza Radwańskiego z 8 czerwca 1944 przywołany jest w: W. Wójcik: Legenda Piłsudskiego w polskiej literaturze międzywojennej. Katowice 1986, s. 232-233 - cyt. za: ibidem, s. 326.

${ }^{60}$ Por. ibidem.

${ }^{61}$ Ibidem, s. 336.

${ }^{62}$ Por. ibidem, s. 330.
} 
ci Marszałka widzi kogoś, kto rozumie i chroni samo sedno demokracji. To dość jasne usprawiedliwienie, choć należałoby rozmawiać o tym, czym dokładnie miałyby być dla Piłsudskiego owe podstawy. Ciekawe jest i to, co dzieje się w dedykacji poprzedzającej właściwy tekst Totalizmu czy kultury. Autor wskazuje, że jej adresat w geście emancypacji narodu pozostawił niektóre sprawy „niedopowiedziane”, by jego następcy mogli wypełniać je treścią i tym samym stawać się współpracownikami Marszałka. Ta uwaga Mysłakowskiego właściwie odbiera możliwość formułowania definitywnych ocen działalności Józefa Piłsudskiego, skoro albo rozumienie jego postaci wykracza poza ramy tego, co możliwe do zrozumienia (bo nie wiemy, co jest niedopowiedziane), albo postać ta okazuje się projektem (celowo) niedokończonym. Zwróćmy uwagę na jeszcze jedno sformułowanie Mysłakowskiego. Oto Piłsudski sam z sobą niegdyś stoczył walkę o prawdę narodu niczym Jakub z aniołem. Bohater motywu biblijnego, mocując się z aniołem a może i z samym Bogiem - nie zostaje pokonany; Jakub zostaje osłabiony - w walce zostaje mu zwichnięty przez przeciwnika staw biodrowy (Rdz 32,25-30). O jaką jednak walkę mogło chodzić Mysłakowskiemu?

\section{Ad astra $^{63}$}

Podobno Marszałek rzadko rozstawał się z Potopem Henryka Sienkiewicza $^{64}$ i wielokrotnie do lektury tej książki wraca ${ }^{65}$. Czytał Potop, gdy przygotowywał się do spotkań w Spójni, kole samokształceniowym z czasów gimnazjalnych. Bohdan Urbanowski odnotowuje informację z okresu wyprawy wileńskiej i wojny z bolszewikami: „12 kwietnia 1919 Piłsudski wyjechał z Warszawy do Skrzybowiec, które miały być jego kwaterą. Na drogę zabrał Potop i Kronikę Stryjkowskiego, bez których się nigdzie nie ruszał. Prócz tych książek woził ze sobą zawsze medalik Matki Boskiej Ostrobramskiej i - od niedawna - fotografię Wandzi - wówczas jeszcze jedynej swej córki, urodzonej 7 lutego 1918 roku (młodsza, Jadwiga, urodzi się za rok)"66. W Potopie, jak do-

${ }^{63}$ Zwrot nawiązuje do strategii myślowej pokazanej przez Rolanda Barthes'a, w której afirmacja czegoś staje się ostateczna wówczas, gdy dokonana jest pomimo przedstawionych wad tego czegoś. Por. R. Barthes: Operacja Astra. W: Idem: Mitologie. Przeł. A. Dziadek. Wstępem opatrzył K. Kłosiński. Warszawa 2000, s. 66-68.

${ }^{64}$ Lektury Marszałka. Muzeum Józefa Piłsudskiego w Sulejówku. https://muzeumpilsudskiblog.pl/lektury-marszalka/ [dostęp: 23.12.2020].

${ }^{65}$ Lektury Józefa Piłsudskiego. Edusens.pl. http://www.edusens.pl/edusensacje/lektury-jozefa-pilsudskiego [dostęp: 23.12.2020].

${ }^{66}$ B. Urbankowski: Józef Piłsudski. Marzyciel i strateg. Poznań 2014, s. 250. 
strzega Ryszard Koziołek, „zieje wyrwa po ojcu”67, powieść tkana jest symboliczną jego nieobecnością, niemożnością prawomocnej sukcesji po nim. Brak ten wywołuje pytania „o powieściowy projekt władcy i ojca idealnego, a także o to, na czym opiera się wyraźna równowaga sił politycznych, militarnych, a nawet erotycznych w powieści. Inaczej mówiąc, kto zamiast »ojca« jest źródłem autorytetu w świecie Potopu"68. Koziołek trafnie i w zręczny sposób sugeruje odpowiedź między innymi pochyla się nad słynną sceną rozmowy Zagłoby z Rochem Kowalskim, w której ten pierwszy udowadnia swoje „wujostwo” względem drugiego. Badacz zwraca uwagę, że wujem jest się na mocy relacji z porządku krwi - ojcem w relacji prawnej. Wspomnijmy choćby filar tradycji europejskiej wyobraźni prawniczej - starorzymskie Prawo dwunastu tablic za ojca dziecka uznawało męża matki dziecka, kontekst biologicznego poczęcia był drugorzędny. Tym samym w Potopie zachodzi „symboliczna wymiana genealogii władzy, która różnicuje państwo (ojca) od narodu (matka) na korzyść tego ostatniego. Ojcem może być każdy - sugeruje Zagłoba - ale wuj reprezentuje krew matki, czyli realną, biologiczną łączność z przodkami"69. Oto i mamy tu opozycję między „wujostwem” i „wodzostwem”. Według Koziołka tłumienie prymatu jednostkowej władzy absolutnej silnego ojca dokonuje się we wszystkich planach narracyjnych Potopu. I tu autor Ciat Sienkiewicza uruchamia motyw rzucający światło na związek dedykacji z wywodem Totalizmu czy kultury. Otóż na kartach powieści przemiana samego Kmicica „polega na opanowaniu popędu tyranizowania innych, na wyrzeczeniu się rozkoszy, jakiej dostarcza usunięcie siłą przeszkody (moralnej, prawnej, politycznej)"70. Czy taką właśnie walkę z samym sobą widział w Piłsudskim Mysłakowski?

Ślady przychylności dla Marszałka pomimo jego wad są częste w wypowiedziach międzywojennych intelektualistów. Kiedy Jan Lechoń w 1924 roku na łamach „Wiadomości Literackich” zdaje relację z wywiadu, który przeprowadził z Piłsudskim, wspomina: „idę za nim na górę na ganek, myśląc ciągle, jak i przez drogę: to jest ten człowiek, który w nas budził Polaków, jak w nas budzi ludzi pierwsza miłość, - to on pokazał nam drogę do Polski, prostą, bohaterską i piękną - niech sobie przyjdzie jaka chce polityka: nie zapomnimy mu tego nigdy"71.

${ }^{67}$ R. Koziołek: Ciała Sienkiewicza. Studia o płci i przemocy. Katowice 2015, s. 64 .

${ }^{68}$ Ibidem.

69 Ibidem, s. 65.

${ }^{70}$ Ibidem.

${ }^{71}$ J. Lechoń: U marszałka Piłsudskiego w Sulejówku. „Wiadomości Literackie” 1924, nr 40-42, s. 1, podkr. - Ł.M.M. 
Zofia Nałkowska, opisując swoje spotkanie z Piłsudskim w tym samym 1924 roku, stwierdza, że jest on człowiekiem monologu, że się myli, że ma znaczne wady, lecz w ogóle nie zmienia to jej zachwytu skalą, siłą, ciężarem tej postaci ${ }^{72}$. Sądzę, że ten sam gest afirmacji „pomimo” wykonuje Mysłakowski - ale też Bogdan Nawroczyński. W tomie Oddech myśli. Archiwalia główne (pod redakcją, w wyborze i z obszernym komentarzem Lecha Witkowskiego) znalazł się między innymi pierwszy raz wydany drukiem tekst jego wspomnień, a w nim związany z pogrzebem Józefa Piłsudskiego fragment - sugestywny, świetnie oddający brak akceptacji dla pioniewierania demokracją i jednoczesne uznanie dla Marszałka i związanie z nim. Przytaczam w całości: „Nie byłem przygotowany na taki mróz w maju, uciekłem więc do Warszawy i tu dowiedziałem się, że właśnie umarł Marszałek Piłsudski. Wiadomość ta wstrząsnęła mną. Pochód żałobny jeszcze bardziej pogłębił wrażenie. Wyległa cała Warszawa. Chcąc być bliżej konduktu, poszedłem aż na Pole Mokotowskie. Tam trafiłem na grupę braci zetowych. Biwakowaliśmy na mokrej ziemi, grzejąc się w ciepłych już promieniach słońca. Czekaliśmy długo, aż doszedł nas odgłos werbli żałobnych. Och, te werble! Będę je do śmierci pamiętał! Przyszły, odeszły... Trumna przepłynęła... Wojsko, rodzina, dygnitarze i wielkie mrowie ludzi... też przeminęło. I słońce zwycięstw i sławy, i szczęśliwa gwiazda wodza zagasły nad Polską. Wielkie były osiągnięcia Zmarłego i wielkie błędy... Buntowaliśmy się przeciw nim, a jednak zachowanie się tłumów świadczyło o tym, że ten gwałtowny dyktator zdobył serca niesfornych Polaków. Bolały nas jego wybuchy gniewu, bezprawia, które popełniał, aleśmy kochali wielką moc jego bohaterskiej duszy. To lepiej niż się łasić do koniunkturalnych władców, a w głębi serca pogardzać i nienawidzić. Żal Warszawy był szczery. Łączył się też z niepokojem, co dalej będzie? Mnie po raz pierwszy przeszyło złe przeczucie. Nie byłem pewny, czy następcy Marszałka udźwigną ciężar obowiązków, które na nich spadły"73.

Wydaje się, że inteligencja okresu międzywojnia dysponowała szerszą wyobraźnią polityczną niż inteligencja z początków XXI wieku. Przede wszystkim była zaopatrzona w chęć historycznego porządkowania zdarzeń. W listopadzie 1937 roku Maciej Starzewski, profesor prawa Uniwersytetu Jagiellońskiego, wygłosił wykład zatytułowany Demokracja a totalizm. Rok później otrzymał tytuł profesora zwyczajnego oraz został posłem na Sejm Rzeczypospolitej Polskiej. We wstępie do wspomnianego wystąpienia zapowiadał, że będzie się starał

72 Z. Nałkowska: Dzienniki. [T.] 3: 1918-1929. Oprac., wstęp i komentarz H. Kirchner. Warszawa 1980.

${ }^{73}$ B. Nawroczyński: Oddech myśli..., s. 342. 
nie sprzyjać żadnej ze stron zawartej w tytule opozycji. Przenikliwie wskazywał zresztą pewne utrudniające zestawienie różnice w ich naturze, jak choćby to, że w przeciwieństwie do demokracji totalizm nie ma treści wewnętrznej („rozsiada się na dwóch odległych biegunach: komunizmu i nacjonalizmu"74). Starzewski uruchomił krytykę z obydwu punktów widzenia, by w momencie, gdy szala argumentów przechylała się na korzyść demokracji, stwierdzić: „A jednak totalizm zwyciężył już w tylu państwach! Demokracja nie dziwi się temu. Nie uważa swojego ustroju za powszechnie wartościowy, - zbyt dobrze zdając sobie sprawę z odmienności warunków bytu każdego narodu, z rozmaitości podłoża historycznego, kulturalnego, psychicznego, socjalnego. Każdy naród buduje sobie taki ustrój, jakiego wymaga etap rozwoju dziejowego, w którym się znajduje. Niewątpliwie istnieją takie położenia, w których demokracja nie znajduje odpowiedniej dla siebie gleby i właściwego klimatu; musi wówczas ustąpić miejsca ustrojowi opartemu na innych zasadach"75. W kolejnym fragmencie Starzewski stwierdzał, iż upadek demokracji wynika z niebezpieczeństw wewnętrznych, i pokazywał, jak totalizm (niewolny od „zarazków”) jest w stanie je zażegnać, by przygotować podłoże pod powrót idei demokratycznych. Być może podobnie o nieadekwatności demokracji do jakiegoś stadium rozwoju wspólnoty myślał cytowany tu Ludwik Chmaj. Znamiona tej perspektywy widzę także w książce Mysłakowskiego, który wprost skłania się ku ideom demokratycznym, jednocześnie aprobując bagatelizowanie ich przez charyzmatyczną postać Piłsudskiego.

\section{Zakończenie}

Lektura międzywojennych diagnoz wydaje się dziś szczególnie cenna, choć minimum uczciwości intelektualnej domaga się, by założyć, że owoce tej lektury posłużą zwolennikom zarówno demokracji, jak i totalizmu. Timothy Snyder w swoich rozważaniach pokazuje, że dojmująco dotyczą nas skutki lektur tej ostatniej grupy: „Historia nigdy się nie kończy i zawsze pojawiają się możliwości alternatywne. Jedną z nich jest Iljin"76. Przypomnieć tu warto świetny esej Josifa Brodskiego Strategia obrony, w którym opisuje on możliwość oporu wobec zła społecznego, ostatecznie jednak konkluduje wypowiedź wyrażeniem

\footnotetext{
${ }^{74}$ M. Starzewski: Demokracja a totalizm. Odczyt wygłoszony w Klubie Dyskusyjnym Związku Legionistów w Krakowie dn. 4 listopada 1937 r. Kraków 1937, s. 13.

${ }^{75}$ Ibidem, s. 43.

${ }^{76}$ T. Snyder: Droga do niewolności..., s. 29.
} 
nadziei, iż ofiara zła zawsze okaże się bardziej pomysłowa i oryginalna w myśleniu, bardziej śmiała niż jej prześladowca ${ }^{77}$. Jak sądzę, ćwiczeniem kondycji potrzebnej do tych zmagań jest między innymi wydobywanie konkurencyjnych narracji z przeszłości.

Oczywiście, nie jest tak, że współcześnie omawiana książka Zygmunta Mysłakowskiego nie rodzi ważnych analiz. Samą postać autora Totalizmu czy kultury wpisuje Lech Witkowski w Wielkie Pokolenie pedagogiki polskiej. Pochylając się nad książką Mysłakowskiego z 1938 roku (jako pierwszą w strukturze analiz), Witkowski wskazuje w niej między innymi na tezy wyprzedzające kontekst poglądów Ericha Fromma. Ten ostatni wątek szczególnie intensywnie został wyeksploatowany przez Marka Kornata w tekście Zygmunt Mysłakowski i jego koncepcja „ucieczki od wolności”78, natomiast o prekursorskim, bo jeszcze przed Baudrillardem, operowaniu w książce Mysłakowskiego kategorią symulakrów kontekstowo pisze Bogusław Śliwerski ${ }^{79}$. Zresztą ten ostatni autor w innym jeszcze miejscu wykorzystuje Totalizm czy kulturę jako podstawowe narzędzie swojego komentarza do stanu świadomości polityków czasów najnowszych ${ }^{80}$.

W czwartej dekadzie XX wieku aura totalizmów unosiła się nad Europą, by skrystalizować się w dramatycznych wydarzeniach II wojny światowej, a potem w kontekście polskim w czasach PRL-u. Jestem zdania, że świadomość historyczna pokoleń międzywojnia górowała nad naszą i przez to dysponowały one między innymi większą zdolnością do uzmysłowienia sobie dwoistych napięć życia społecznego, która pozwalała na zrozumienie tego, że dyktatura totalizmu nie jest w decydującym stopniu efektem niemoralnej osobowości wodza, lecz wynikiem realnych, trudnych do negowania potrzeb wspólnoty wynikających z jej psychologicznego profilu. Jednocześnie zauważmy, że wybuch wojennych totalizmów jest znakiem, że była to świadomość niewystarczająca. Tym bardziej niepokojąca jest diagnoza Snydera, iż początek XXI wieku rodzi pokolenia ahistoryczne, o krótkiej wyobraźni czasowej, więc skłonne do myślenia ostrymi alternatywami: albo - albo. Epilog

${ }^{77}$ J. Brodski: Strategia obrony. Tłum. A. Pokojska. „Rzeczpospolita”, 21-22.01.2006, dodatek: „Plus Minus”, s. 8-9.

${ }^{78}$ M. Kornat: Zygmunt Mysłakowski i jego koncepcja „ucieczki od wolności”. W: Doktryny, historia, władza. Red. A. Citkowska-Kimla, M. Kiwior-Filo, B. Szlachta. Kraków 2009, s. 137-151.

79 B. Śliwerski: „Spropagowany” pedagog społeczny jako uczony w przestrzeni politycznych konfrontacji. W: Pedagog społeczny. Teoria i praktyka działalności społecznej. Red. A. Żukiewicz. Łódź 2017, s. 13-29. https://doi.org/10.18778/8088642-1.02.

80 B. Śliwerski: Tęsknota do „wodza”. Pedagog, 8.04.2019. https://sliwerski-pedagog.blogspot.com/2019/04/tesknota-do-wodza.html [dostęp: 23.12.2020]. 
książeczki O tyranii Snydera zatytułowany jest Historia i wolność. Pisze tu autor: „Jeżeli chcemy potwierdzić swoje przywiązanie do wolności, musimy przywrócić porządek w naszym poczuciu czasu" ${ }^{\text {"1. }}$.

W trybie postscriptum raz jeszcze Zygmunt Mysłakowski, który na ostatnich stronach książki formułuje opis antidotum na rozwijającą się w społeczeństwach w jego czasach chorobę totalizmu. Autor chce dążenia do „demokracji społecznej ulepszonej i dostosowanej do współczesnych form wiedzy, techniki i propagandy. Przejść mogą tylko nieżyciowe formy demokracji, sama istota jej ostać się musi. Człowiek potrzebuje nie tylko wzorowo i higienicznie urządzonej klatki - potrzebuje także wolności indywidualnej dla swego intelektu, uczuć i wierzeń - potrzebuje minimum wolności społecznej dla zrzeszeń i związków różnego rodzaju, pełniących rolę ogniw pośrednich pomiędzy nim a państwem. Pozbawiony tych koniecznych warunków swej egzystencji moralnej, nie oparty o bliskie i dostępne mu formy zespołowe, poprzez które jedynie uspołeczniać się może - zostaje postawiony wobec nienawistnego, depcącego po nim molocha super-organizacji, lub też wobec konwulsyjnych miotań się mas, histerycznie pobudzanych przez proroków i ich impresariów" ${ }^{\prime 2}$. Być przejętym widmem ostatecznej katastrofy i motywowanym nią do działania, a jednocześnie widzieć siebie jako część przemian historycznych, w których zwykle czasem dramatycznym żywią się kolejne renesanse - czy na drodze do wolności możliwy jest inny prowiant?

\section{Bibliografia}

Barthes R.: Operacja Astra. W: Idem: Mitologie. Przeł. A. Dziadek. Wstępem opatrzył K. Kłosiński. Warszawa 2000, s. 66-68.

Brodski J.: Strategia obrony. Tłum. A. Pokojska. „Rzeczpospolita”, 21-22.01.2006, dodatek: „Plus Minus”, s. 8-9.

Chmaj L.: Kierunki i prądy pedagogiki współczesnej. Warszawa-Wilno 1938.

Kołakowski L.: Niepewność epoki demokracji. Wybór i słowo wstępne Z. Mentzel. Kraków 2014.

${ }^{81}$ T. Snyder: O tyranii. Dwadzieścia lekcji z dwudziestego wieku. Przekł. B. Pietrzyk. Kraków 2017, s. 120.

82 Z. Mysłakowski: Totalizm czy kultura..., s. 76. 
Kornat M.: Zygmunt Mysłakowski i jego koncepcja „ucieczki od wolności”. W: Doktryny, historia, władza. Red. A. Citkowska-Kimla, M. Kiwior-Filo, B. Szlachta. Kraków 2009, s. 137-151.

Kowal G.: Anatomia kulturowej legendy. Niżyński, Gründgens, Dönhoff, Piłsudski. Kraków 2014.

Koziołek R.: Ciała Sienkiewicza. Studia o płci i przemocy. Katowice 2015.

Lechoń J.: U marszałka Piłsudskiego w Sulejówku. „Wiadomości Literackie” 1924, nr 40-42, s. 1.

Lektury Józefa Piłsudskiego. Edusens.pl. http://www.edusens.pl/edusensacje/lektury-jozefa-pilsudskiego [dostęp: 23.12.2020].

Lektury Marszałka. Muzeum Józefa Piłsudskiego w Sulejówku. https:// muzeumpilsudskiblog.pl/lektury-marszalka/ [dostęp: 23.12.2020].

Miłosz C.: Zniewolony umyst. Paryż 1953.

Mysłakowski Z.: Totalizm czy kultura. Kraków 1938.

Nałkowska Z.: Dzienniki. [T.] 3: 1918-1929. Oprac., wstęp i komentarz H. Kirchner. Warszawa 1980.

Nawroczyński B.: Oddech myśli. Archiwalia główne. Wybór, komentarze i red. naukowa L. Witkowski. Kraków 2020.

Snyder T.: Droga do niewolności. Rosja, Europa, Ameryka. Przekł. B. Pietrzyk. Kraków 2019.

Snyder T.: O tyranii. Dwadzieścia lekcji z dwudziestego wieku. Przekł. B. Pietrzyk. Kraków 2017.

Starzewski M.: Demokracja a totalizm. Odczyt wygłoszony w Klubie Dyskusyjnym Związku Legionistów w Krakowie dn. 4 listopada 1937 r. Kraków 1937.

Śliwerski B.: „Spropagowany” pedagog społeczny jako uczony w przestrzeni politycznych konfrontacji. W: Pedagog społeczny. Teoria i praktyka działalności społecznej. Red. A. Żukiewicz. Łódź 2017, s. 13-29. https://doi. org/10.18778/8088-642-1.02.

Śliwerski B.: Tęsknota do „wodza”. Pedagog, 8.04.2019. https://sliwerski-pedagog.blogspot.com/2019/04/tesknota-do-wodza.html [dostęp: 23.12.2020].

Urbankowski B.: Józef Piłsudski. Marzyciel i strateg. Poznań 2014.

Weber M.: Gospodarka i społeczeństwo. Zarys socjologii rozumiejącej. Przeł. i wstępem opatrzyła D. Lachowska. Warszawa 2002.

Witkowski L.: Przełom dwoistości w pedagogice polskiej. Historia, teoria, krytyka. Kraków 2013. 